\title{
Motivasi Petani dalam Budidaya Tanaman Kelapa Sawit (Elais guineensis Jacq) di Desa Silebo-lebo, Kecamatan Kutalimbaru, Kabupaten Deli Serdang
}

Firman RL Silalahi ${ }^{1 *}$, Yusra Muharami Lestari ${ }^{1}$, Jontara Hutabalian ${ }^{1}$

${ }^{1}$ Politeknik Pembangunan Pertanian Medan

\begin{tabular}{l}
\multicolumn{1}{c}{ ARTIKEL INFO } \\
\hline Sejarah artikel \\
Diterima 03/12/2020 \\
Diterima dalam bentuk revisi 27/01/2021 \\
Diterima dan disetujui 22/02/2021 \\
Tersedia online 22/06/2021 \\
\hline Kata kunci \\
Budidaya \\
Motivasi petani \\
Kelapa sawit \\
\hline
\end{tabular}

\begin{abstract}
ABSTRAK
Penyumbang devisa terbesar Indonesia adalah sektor pertanian yaitu kelapa sawit. Kecamatan Kutalimbaru yang terletak di Kabupaten Deli Serdang, Provinsi Sumatera Utara memiliki potensi tanaman kelapa sawit, dimana terdapat 728,5 Ha lahan kelapa sawit yang berasal dari 6 desa dan salah satunya adalah Desa Silebo-lebo. Produktivitas rata rata yang yang dimiliki oleh petani kelapa sawit Desa Silebo-lebo tergolong rendah jika dibandingkan dengan rata-rata produktivitas kelapa sawit yang ada di Indonesia yang mencapai angka 30 ton/Ha/thn. Berdasarkan wawancara dengan penyuluh dan petani, kurangnya produktivitas disebabkan teknik budidaya yang dilakukan oleh petani kurang baik namun petani tetap teguh untuk bebudidaya kelapa sawit. Tujuan dari penelitian ini adalah untuk mengetahui tingkat motivasi petani (motivasi ekonomi dan motivasi sosiologis) dan untuk mengetahui tingkat faktor-faktor motivasi petani dalam budidaya tanaman kelapa sawit (Elaeis guineensis Jacq) di Desa Silebo-lebo, Kecamatan Kutalimbaru, Kabupaten Deli Serdang. Data pada penelitian ini diperoleh melalui metode wawancara dan studi kepustakaan, yang dianalisis menggunakan metode deskriptif. Hasil dari penelitian diperoleh bahwa tingkat motivasi petani dari segi ekonomi dalam budidaya kelapa sawit yang baik di Desa Silebo-lebo, Kecamatan Kutalimbaru, Kabupaten Deli Serdang dalam kategori sedang yaitu sebesar 48,8\% dan tingkat motivasi petani dari segi sosiologis dalam kategori sedang yaitu sebesar 46,1\%. Dari hasil penelitian juga diperoleh bahwa dari faktor-faktor eksternal maupun faktorfaktor internal yang diteliti faktor yang paling berpengaruh adalah tingkat ketersedian kredit usahatani dengan kategori tinggi yaitu sebesar $73,88 \%$.
\end{abstract}

(C) 2021 Politeknik Pembangunan Pertanian Manokwari

*Email Penulis Korespondensi : firman.rlsilalahi@ gmail.com

1yusramuharami@gmail.com 


\section{ABSTRACT}

The largest contributor to foreign exchange in Indonesia is from the agricultural sector, namely oil palm. Kutalimbaru Subdistrict, located in Deli Serdang Regency, North Sumatra Province, has the potential for oil palm plants, where there are 728.5 hectares of oil palm land from 6 villages and one of them is Silebo-lebo Village. The average productivity of oil palm farmers in Silebo-lebo Village is low when compared to the average productivity of oil palm in Indonesia which reaches 30 tonnes/ha/year. Based on interviews with extension agents and farmers, the lack of productivity is due to poor cultivation techniques, but farmers are persistent in cultivating oil palm. The purpose of this study was to determine the level of farmer motivation (economic motivation and sociological motivation) and to determine the level of motivational factors for farmers in cultivating oil

\section{PENDAHULUAN}

Kelapa Sawit merupakan produk unggulan dan telah menjadi komoditas perdagangan internasional yang menyumbang devisa terbesar di dunia bagi negara ekspor non migas tanaman perkebunan. Kecamatan Kutalimbaru merupakan salah satu kecamatan di Kabupaten Deli Serdang yang memiliki potensi tanaman kelapa sawit. Kecamatan Kutalimbaru memiliki 728,5 Ha yang terdiri dari 6 desa di kecamatan tersebut salah satunya adalah Desa Silebo-lebo yang memiliki lahan kelapa sawit cukup luas. Desa Silebo-lebo memiliki luas lahan kelapa sawit 149,6 Ha. Produktivitas kelapa sawit di Desa Silebo-lebo menurut data statistik Dinas Perkebunan Sumatera Utara bahwa rata rata tandan buah segar hanya 15-18 ton/Ha/tahun. Produktivitas rata rata yang dimiliki oleh petani kelapa sawit Desa Silebo-lebo tergolong rendah jika dibandingkan dengan rata-rata produktivitas kelapa sawit rakyat Indonesia yang mencapai angka 30 ton/Ha/thn. Menurut Pahan (2007) palm (Elaeis guineensis Jacq) in Silebo-lebo Village, Kutalimbaru District, Deli Serdang Regency. The data in this study were obtained through interview and literature study methods, which were analyzed using descriptive methods. The results of the study showed that the level of motivation of farmers from an economic point of view in good oil palm cultivation in Silebo-lebo Village, Kutalimbaru District, Deli Serdang Regency was in the medium category, namely $48.8 \%$ and the level of motivation of farmers from a sociological point of view in the moderate category was 46, 1\%. From the research results also obtained that from the external factors as well as the internal factors studied, the most influential factor was the level of farm credit availability with a high category of $73.88 \%$.

suatu daerah dengan tingkat produksi tinggi memiliki tingkat produksi Tandan Buah Segar (TBS) kelapa sawit mencapai 3 ton/Ha/bln. Berdasarkan wawancara dengan penyuluh dan petani, permasalahan yang dihadapi oleh petani kelapa sawit yang ada di Desa Silebo-lebo yaitu kurangnya produktivitas yang disebabkan teknik budidaya yang dilakukan oleh petani kurang baik namun petani tetap teguh walaupun masih ada tanaman lain yang bisa di budidayakan seperti tanaman kakao, kemiri, dan jambu biji. Keteguhan petani dalam budidaya tanaman kelapa sawit dipengaruhi oleh faktor internal dan faktor eksternal. Faktor internal bersumber dari dalam diri individu itu sendiri, sedangkan faktor eksternal bersumber dari lingkungan (Danim, 2012). Faktor-faktor dari dalam diri petani ialah faktor yang berasal dari internal petani, yaitu status sosial ekonomi petani (Silalahi, Masrizal, \& Marbun, 2014). Status sosial ekonomi dalam masyarakat dapat dimengerti melalui apa yang dimiliki oleh individu-individu ataupun melalui kemampuan 
kepala keluarga untuk mengusahakannya, misalnya dengan kekuasaan ataupun kewenangan yang dimiliki (Dewandini, 2010). Keteguhan petani ini juga sangat erat hubungannya dengan tingkat motivasi petani itu sendiri yaitu motivasi ekonomi dan motivasi sosiologi dalam budidaya tanaman kelapa sawit. Melihat kondisi ini, dimana saat ini produktifitas dapat dikatakan rendah tetapi petani masih mempunyai keteguhan terhadap budidaya tanaman kelapa sawit.

Tujuan dari penelitian ini adalah untuk mengetahui tingkat motivasi petani (motivasi ekonomi dan motivasi sosiologis) dan untuk mengetahui tingkat faktor-faktor motivasi petani dalam budidaya tanaman kelapa sawit (Elaeis guineensis Jacq) di Desa Silebo-lebo, Kecamatan Kutalimbaru, Kabupaten Deli Serdang.

\section{METODE}

Pelaksanaan penelitian dilakukan dengan menggunakan metode deskriptif yang mencoba menggambarkan suatu kejadian atau fenomena di lokasi penelitian. Jenis metode deskriptif yang digunakan adalah survei yaitu penelitian yang dilakukan dengan cara menyusun daftar pertanyaan/pernyataan yang diajukan pada responden, digunakan untuk meneliti gejala suatu kelompok atau perilaku individu, dan penggalian data melalui kuesioner dan wawancara. Alat dan bahan yang digunakan yaitu: kuesioner, buku catatan, pena, kamera, literatur tentang budidaya kelapa sawit dan lain sebagainya yang dapat mendukung kegiatan penelitian. Penelitian dilaksanakan pada tanggal 25 Maret s.d 24 Mei 2019 di Desa
Silebo-lebo, Kecamatan Kutalimbaru Kabupaten Deli Serdang, Provinsi Sumatera Utara. Populasi dalam penelitian ini adalah kelompok tani yang berusahatani tanaman kelapa sawit yaitu sebanyak 185 orang. Penentuan sampel dalam pengkajian ini dilakukan dengan menggunakan metode simple random sampling dengan menggunakan rumus Yamane dan diperoleh sampel sebanyak 36 orang. Teknik pengumpulan data yang dilakukan dalam pelaksanaan penelitian ini menggunakan kuesioner sebagai alat pengumpul data. Kuesioner yang digunakan dilakukan uji validitas dan reliabilitas terlebih dahulu. Validitas digunakan untuk melihat kelayakan butir-butir pertanyaan suatu variabel dalam kuesioner (Noor, 2011) sedangkan uji reliabilitas dimaksudkan untuk menilai kestabilan ukuran dan konsistensi responden dalam menjawab kuesioner. Untuk mengkaji tingkat motivasi petani dalam budidaya tanaman kelapa sawit (Elaeis guineensis Jacq) di Desa Silebo-lebo, Kecamatan Kutalimbaru, Kabupaten Deli Serdang dengan menggunakan skala likert dengan ketentuan sebagai berikut:

Tingkat Motivasi $=$ $\frac{\text { Total Nilai yang diperoleh }}{\text { Nilai Maksimum yang dicapai }} \times 100 \%$

Keterangan: Kriteria Interpretasi Skor (Riduwan, 2008)

$$
\begin{array}{ll}
0 \%-20 \% & =\text { Sangat Rendah } \\
21 \%-40 \% & =\text { Rendah } \\
41 \%-60 \% & =\text { Sedang } \\
61 \%-80 \% & =\text { Tinggi } \\
81 \%-100 \% & =\text { Sangat Tinggi }
\end{array}
$$


Untuk mengkaji tingkat faktor- faktor motivasi petani dalam budidaya tanaman kelapa sawit (Elaeis guineensis Jacq) di Desa Silebolebo, Kecamatan Kutalimbaru, Kabupaten Deli Serdang, dilakukan tabulasi data yang diperoleh dalam pengumpulan data menggunakan kuisioner kemudian data dimasukkan ke dalam tabel frekuensi. Setelah hal tersebut didapatkan maka langkah selanjutnya adalah menghitung tingkat motivasi secara keseluruhan dengan menggunakan skala likert dengan ketentuan sebagai berikut:

Tingkat faktor - faktor $=$ $\frac{\text { Total Nilai yang diperoleh }}{\text { Nilai Maksimum yang dicapai }} \times 100 \%$
Keterangan: Kriteria Interpetasi Skor (Riduwan, 2008)

$$
\begin{array}{ll}
0 \%-20 \% & =\text { Sangat Rendah } \\
21 \%-40 \% & =\text { Rendah } \\
41 \%-60 \% & =\text { Sedang } \\
61 \%-80 \% & =\text { Tinggi } \\
81 \%-100 \% & =\text { Sangat Tinggi }
\end{array}
$$

\section{HASIL DAN PEMBAHASAN}

\section{Tingkat Motivasi Ekonomi (Y1)}

Motivasi ekonomi yaitu kondisi yang mendorong petani untuk memenuhi kebutuhan ekonomi. Pengukuran motivasi ekonomi

\begin{tabular}{|c|c|c|c|c|c|c|}
\hline No & Motivasi Ekonomi & Kategori & Nilai & Jumlah & Skor & $\%$ \\
\hline 1 & $\begin{array}{l}\text { Keinginan untuk memiliki } \\
\text { dan } \\
\text { tabungan }\end{array}$ & Sangat tinggi & 5 & 3 & 15 & 8,3 \\
\hline 2 & $\begin{array}{l}\text { Keinginan untuk } \\
\text { memperoleh pendapatan } \\
\text { yang lebih tinggi }\end{array}$ & Tinggi & 4 & 1 & 4 & 2,8 \\
\hline 3 & $\begin{array}{l}\text { Keinginan untuk hidup } \\
\text { lebih sejahtera atau lebih } \\
\text { baik }\end{array}$ & Sedang & 3 & 5 & 15 & 13,9 \\
\hline 4 & $\begin{array}{l}\text { Keinginan untuk } \\
\text { memenuhi kebutuhan }\end{array}$ & Rendah & 2 & 27 & 54 & 75 \\
\hline 5 & $\begin{array}{l}\text { Keinginan untuk membeli } \\
\text { barang- barang mewah }\end{array}$ & Sangat rendah & 1 & - & - & - \\
\hline \multicolumn{2}{|c|}{ Jumlah } & & & 36 & 88 & 100 \\
\hline \multicolumn{2}{|c|}{ Skor yang diperoleh } & & & & 88 & \\
\hline \multicolumn{2}{|c|}{ Skor ideal } & & & & 180 & \\
\hline
\end{tabular}
dilakukan dengan lima indikator. Analisa motivasi ekonomi responden disajikan pada Tabel 1.

Tabel 1. Kategori Motivasi Ekonomi Responden

Berdasarkan Tabel 1. dapat dilihat jumlah skor yang diperoleh 88, skor ideal (skor tertinggi) 180 dengan tingkat motivasi ekonomi sebagai berikut:
Tingkat Motivasi Ekonomi $=\frac{88}{180} \times 100 \%$ $=48,11 \%$ 
Tingkat ekonomi yang didapatkan adalah $48,11 \%$ Secara kontinum dapat dilihat pada Gambar 1.

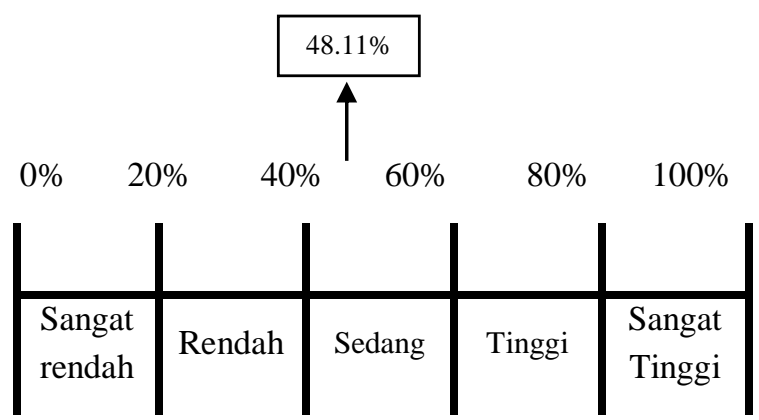

Gambar 1. Garis Kontinum Persentase Tingkat Motivasi Petani

Berdasarkan Tabel 1 dapat dilihat kategori rendah sebanyak $75 \%$, responden yang menjawab rendah sebanyak 27 responden, sedangkan yang menjawab kategori sedang sebanyak $13 \%$ atau yang menjawab kategori rendah sebanyak 5 responden, kategori yang menjawab sangat tinggi sebanyak $8,3 \%$ atau

Tabel 2. Kategori Motivasi Sosiologis Responden sebanyak 3 responden, dan yang menjawab kategori tinggi sebanyak 2,8 atau sebanyak 1 responden. Dari jawaban responden setelah dilakukan perhitungan didapat jumlah skor yang diperoleh 80 sedangkan skor ideal 180 maka didapatkan tingkat motivasi petani dalam budidaya tanaman kelapa sawit sebesar 48,8. Artinya tingkat motivasi petani dalam budidaya tanaman kelapa sawit dalam kategori sedang.

\section{Tingkat Motivasi Sosiologis (Y2)}

Motivasi sosiologis yaitu kondisi yang mendorong petani memenuhi kebutuhan sosial dan berinteraksi dengan orang lain karena petani hidup bermasyarakat. Pengukuran motivasi sosiologis dilakukan dengan melakukan pertanyaan langsung kepada responden. Analisis motivasi sosiologis disajikan pada Tabel 2.

\begin{tabular}{|c|c|c|c|c|c|c|}
\hline No & Motivasi sosiologis & Kategori & Nilai & Jumlah & Skor & $\%$ \\
\hline 1 & $\begin{array}{l}\text { Keinginan untuk } \\
\text { menambah relasi atau } \\
\text { teman }\end{array}$ & Sangat tinggi & 5 & - & - & - \\
\hline 2 & $\begin{array}{l}\text { Keinginan untuk } \\
\text { bekerjasama dengan } \\
\text { orang lain }\end{array}$ & Tinggi & 4 & 1 & 4 & 2,8 \\
\hline 3 & $\begin{array}{l}\text { Keinginan untuk } \\
\text { mempererat } \\
\text { kerukunan }\end{array}$ & Sedang & 3 & 11 & 33 & 30,5 \\
\hline 4 & $\begin{array}{l}\text { Keinginan untuk dapat } \\
\text { bertukar pikiran }\end{array}$ & Rendah & 2 & 24 & 46 & 66,7 \\
\hline 5 & $\begin{array}{l}\text { Keinginan untuk } \\
\text { memperoleh bantuan } \\
\text { dari pihak lain }\end{array}$ & Sangat rendah & 1 & - & - & - \\
\hline \multicolumn{5}{|c|}{ Jumlah } & 83 & 100 \\
\hline \multicolumn{3}{|c|}{ Skor yang diperoleh } & & 83 & & \\
\hline \multicolumn{3}{|c|}{ Skor ideal } & & 180 & & \\
\hline
\end{tabular}

Berdasarkan tabel 2 dapat dilihat skor yang diperoleh sebanyak 83, skor ideal sebanyak 180 maka didapatkan tingkat motivasi ekonomi sebagai berikut: 
Tingkat Motivasi Sosiologis $=\frac{8883}{180} \times 100 \%$ $=46,1 \%$

Tingkat motivasi sosiologis yang didapatkan adalah 46,1\% Secara kontinum dapat dilihat pada Gambar 2.

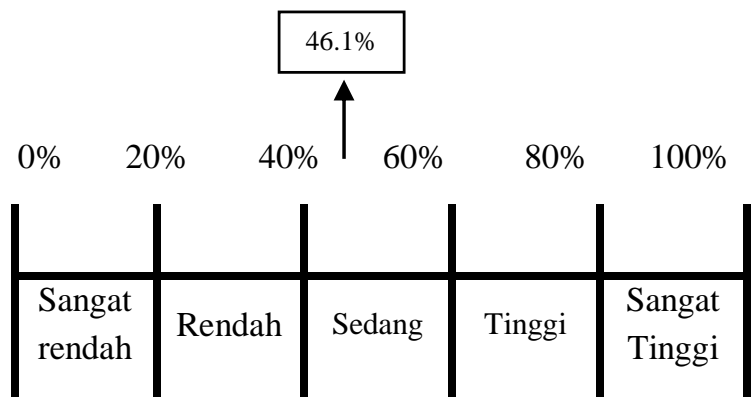

Gambar 2. Garis Kontinum Persentase Tingkat

Motivasi Petani

Berdasarkan Tabel 2, faktor motivasi petani dalam budidaya tanaman kelapa sawit, dimana jumlah skor yang diperoleh 83 sedangkan skor ideal 180. Dapat dijelaskan bahwa faktor motivasi petani dalam kehidupannya dewasa ini tidak dapat memenuhi kebutuhannya tanpa bantuan orang lain, baik kebutuhan ekonomis maupun kebutuhan sosiologisnya. Keadaan dilapangan bahwa petani responden dalam dalam budidaya tanaman kelapa sawit berkeinginan besar untuk memenuhi faktor motivasinya sehingga persentase faktor motivasi petani dalam budidaya tanaman kelapa sawit dalam kategori sedang $(46,1 \%)$. Tinggi rendahnya motivasi seseorang ditentukan oleh tiga komponen (Uno, 2016) yaitu: ekspektasi (harapan), instrumentalis (keberhasilan tugas untuk mendapatkan outcome tertentu) dan Valensi, yaitu respon terhadap outcome seperti perasaan posistif, netral, atau negatif. Motivasi tinggi jika usaha menghasilkan sesuatu yang melebihi harapan motivasi rendah jika usahanya menghasilkan kurang dari yang diharapkan.

\section{Tingkat Faktor- Faktor Internal}

Karakteristik responden digunakan untuk mengetahui keragaman dari responden berdasarkan faktor internal. Hal tersebut diharapkan dapat memberikan Gambaran yang cukup jelas mengenai kondisi dari responden dan kaitannya dengan masalah dan tujuan penelitian tersebut. Data yang didapat terkait dengan identitas responden, karakteristik yang dimiliki petani yaitu suatu tanda atau ciri-ciri dari seseorang yang ada didalam diri orang tersebut yang dapat berhubungan dengan seseorang dalam melakukan usaha tani, faktor internal meliputi umur responden, pendidikan formal, pendidikan non formal, pengalaman responden, pendapatan petani, luas lahan, status lahan, tingkat kosmopolitan. Tingkat faktor internal yang diperoleh terlihat dari gambar berikut ini:

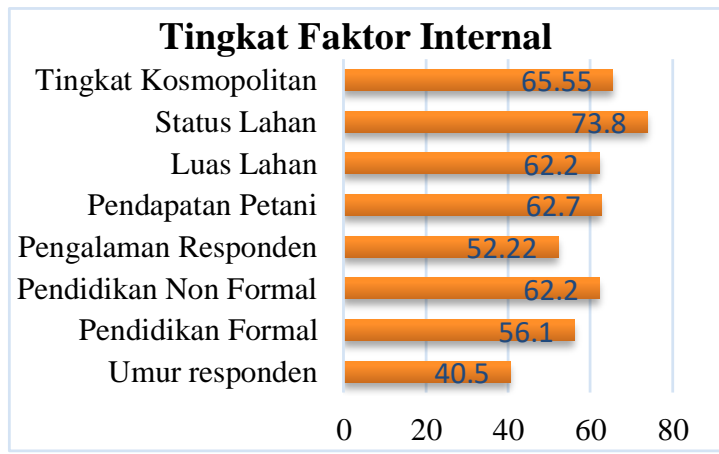

Gambar 3. Tingkat Faktor Internal

Tingkat umur berada pada tingkat sedang yaitu $40 \%$. Kategori responden rata-rata dalam usia produktif, banyak keuntungan yang akan dicapai dengan kondisi ini, karena menurut Mardikanto (1993), petani yang bearada pada kisaran umur 20-50 tahun termasuk umur yang masih produktif untuk mengelola usahatani dan 
dianggap mampu mengadopsi inovasi teknologi yang terus berkembang dengan pesat. Merujuk kepada pendapat Soekartawi bahwasanya petani yang lebih tua tampaknya kurang cenderung melakukan suatu inovasi baru daripada mereka yang relatif umur muda karena semakin muda petani biasanya semakin tinggi rasa ingin tahu, sehingga dengan itu mereka berusaha untuk lebih cepat termotivasi dalam melakukan budidaya tanaman kelapa sawit dengan baik.

Tingkat pendidikan formal berada pada tingkat sedang yaitu $56,1 \%$. Tingkat pendidikan petani merupakan salah satu faktor yang sangat penting dan menjadi salah satu indikator dalam pengambilan keputusan dan kualitas kerjanya, khususnya dalam mengadopsi inovasi teknologi dalam berbudidaya kelapa sawit yang baik. Biasanya semakin tinggi pendidikan seseorang maka tingkat pengetahuan seseorang akan semakin tinggi pula. Dengan tingkat pendidikan formal pada kategori sedang mempengaruhi kehidupan petani terutama permasalahan di dalam bidang pekerjaan yang ditekuni, dari kecil mereka terdidik untuk menganut pola bermasyarakat secara tradisonal dan cenderung mengikuti orang tua mereka yang memanfaatkan lahan sekitar untuk bercocok tanam sebagai sumber penghasilan utama dalam kehidupan sehari-hari mereka (Nisa, 2015). Tingkat pendidikan nonformal berada pada tingkat tinggi yaitu $62,2 \%$. Hasil ini menunjukkan semakin sering petani mengikuti kegiatan diskusi di bidang pertanian, maka informasi yang diperoleh akan semakin banyak. Dalam diskusi kelompok ini petani dapat saling bertukar pikiran tentang masalah-masalah yang dihadapi dalam proses budidaya ataupun mengenai terobosan atau teknologi baru yang dapat meningkatkan hasil dari usahatani (Makendra, 2016). Hal ini membuat pengaruh terhadap keterampilan petani dalam mengelola usahataninya.

Tingkat pengalaman petani berbudidaya kelapa sawit berada pada tingkat sedang yaitu $52,2 \%$. Tingkat pendapatan berada pada tingkat tinggi yaitu $62,7 \%$. Dengan pendapatan yang rendah sehingga mereka sulit untuk memenuhi kebutuhan untuk mengoptimalkan dalam mengurus tanaman kelapa sawit. Tidak seimbangnya produksi kelapa sawit mereka membuat pendapatan petani sangat minim di Desa Silebo-lebo.

Tingkat luas lahan berada pada tingkat tinggi yaitu 62,2\%. Luas lahan akan berpengaruh terhadap usaha tani seorang petani dimana semakin tinggi luas lahan petani akan semakin tinggi semangat untuk melakukan suatu budidaya. Tingkat status lahan berada pada tingkat sedang yaitu $73,8 \%$. Status lahan berpengaruh kepada motivasi petani dalam melakukan budidaya khususnya budidaya kelapa sawit. Dimana mereka mempunyai lahan sendiri untuk dijadikan sebagai lahan untuk ditanami kelapa sawit. Tingkat kosmopolitan berada pada tingkat tinggi yaitu 65,55\%. Semakin tinggi seseorang melakukan studi banding dibidang pertanian akan berpengaruh terhadap kinerjanya dibidang pertanian.

\section{Tingkat Faktor-Faktor Eksternal}

Faktor eksternal yaitu kekuatankekuatan ekonomi yang ada dalam masyarakat di lokasi pengkajian yang keberadaannya dapat mendorong atau mengahambat petani dalam 
melakukan budidaya kelapa sawit. Faktor eksternal yang diteliti adalah ketersediaan kredit usaha tani, ketersedian saprodi dan jaminan pasar dengan hasil sebagai berikut:

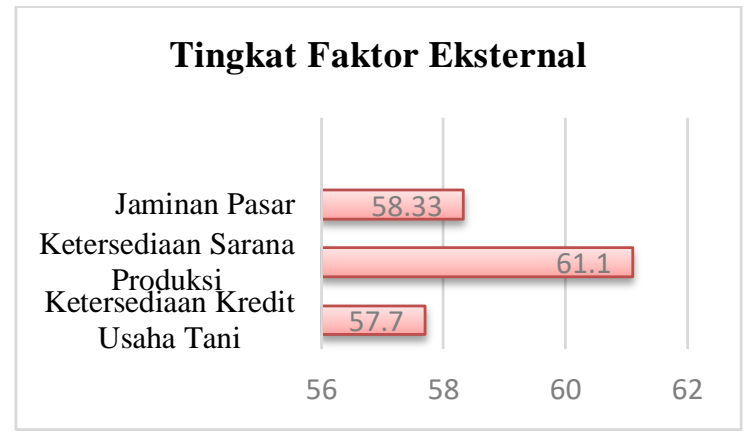

Gambar 4. Tingkat Faktor Eksternal

Ketersediaan kredit usaha tani adalah salah satu faktor pendukung untuk membantu dalam melakukan teknis budidaya khususnya dalam permodalan untuk melakukan semua kegiatan budidaya kelapa sawit. Dapat dilihat bahwa tingkat ketersediaan kredit usahatani berada pada tingkat sedang yaitu 58,8\% Dengan bantuan pihak lain dalam segi bantuan modal untuk petani melakukan usaha taninya seperti bank yang dapat memberi modal untuk menunjang segala usaha yang dilakukan oleh petani akan lebih memudahkan petani melakukan budidaya tanaman kelapa sawit di Desa Silebo-lebo. Tingkat ketersediaan kredit usahatani memang pada kategori sedang namun akan sangat bermanfaat bagi petani di Desa Silebo-lebo. Petani hendaknya lebih berhatihati dalam penggunaan modal dari lembaga yang membebankan bunga yang tinggi (Masrafit, 2013). Lingkungan ekonomi adalah faktor yang cukup memotivasi petani dalam kegiatan usahatani padi sawah salah satu sebabnya karena sebagian responden yang tidak tahu apakah ada lembaga perkreditan yang membantu petani dalam memenuhi kegiatan usahataninya (Agus, 2017). Tingkat ketersediaan sarana produksi yang didapatkan adalah $61,1 \%$. Sarana produksi yang tersedia di daerah ini sangat memudahkan petani untuk memenuhi kebutuhan segala alat ataupun bahan untuk melakukan perawatan pada tanaman kelapa sawit. Tingkat jaminan pasar yang didapatkan adalah $58,8 \%$, Jaminan pasar tentu akan membantu dalam melakukan budidaya kelapa sawit dengan adanya agen yang membeli hasil usaha tani maka akan berpengaruh terhadap harga jual hasil dari kelapa sawit.

\section{KESIMPULAN DAN SARAN}

Berdasarkan analisis dan pembahasan yang mengkaji tentang motivasi petani dalam budidaya tanaman kelapa sawit (Elaeis guineensi Jacq) di Desa Silebo-lebo, Kecamatan Kutalimbaru, Kabupaten Deli Serdang maka dapat disimpulkan tingkat motivasi ekonomi dalam membudidayakan kelapa sawit yang baik di Desa Silebo-lebo, Kecamatan Kutalimbaru, Kabupaten Deli Serdang kategori sedang. Tingkat motivasi sosiologis dalam membudidayakan kelapa sawit yang baik di Desa Silebo-lebo, Kecamatan Kutalimbaru, Kabupaten Deli Serdang kategori sedang. Dari hasil penelitian serta pembahasan tentang tingkat faktor-faktor di Desa Silebo-lebo Kecamatan Kutalimbaru Kabupaten Deli Serdang baik dari segi eksternal maupun internal terlihat bahwa tingkat umur, pengalaman, status kepemilikan lahan, tingkat jaminan pasar dan pendidikan pada kategori sedang, tingkat pendidikan non formal, 
pendapatan, tingkat luas lahan, tingkat kosmopolitan dan tingkat ketersediaan kredit usaha tani, ketersediaan sarana produksi pada kategori tinggi.

\section{DAFTAR PUSTAKA}

Agus, S. T. W. (2017). Faktor-faktor Sosial Ekonomi Yang Memotivasi Petani Melakukan Usaha Tani Padi Sawah (Oryza sativa L.) di Kelurahan Bukuan Kecamatan Palkaran Kota Samarinda. Jurnal Ekonomi Pertanian dan Pembangunan, 78-90.

Danim. (2012). Motivasi Kepemimpinan dan Efektifitas Kelompok. Jakarta: Rineke Cipta.

Dewandini, S. K. (2010). Motivasi Petani Dalam Budidaya Tanaman Mendong (Fimbristylis globulosa) Di Kecamatan Minggir Kabupaten Sleman. Surakarta: Universitas Sebelas Maret.

Makendra, N. (2016). Motivasi Petani Dalam Usahatani Tanaman Bunga Krisan di Desa Hargobinangun Kecamatan Pakem Kabupaten Sleman. Research Repository, University of Muhammadiyah Yogyakarta.

Mardikanto, T. (1993). Penyuluhan Pembangunan Pertanian. Surakarta: Lembaga Pengembangan Pendidikan UNS dan UNS Press.
Masrafit. (2013). Motivasi Petani dalam Melakukan Usahatani Kelapa Sawit di Kecamatan Bakongan Timur Kabupaten Aceh Selatan. Banda Aceh: Universitas Syiah Kuala.

Nisa, N. K. (2015). Motivasi Petani Dalam Menanam Komoditas Pada Daerah Lumbung Padi di Kabupaten Gresik. Swara Bhumi Vol 3 Nomor 3, 80-90.

Noor, J. (2011). Skripsi, Tesis, Disertasi dan Karya Ilmiah. Jakarta: Kencana Prenada Media Group.

Pahan, I. (2007). Panduan Lengkap Kelapa Sawit: Manajemen Agribisnis Dari Hulu Hingga Hilir. Jakarta: Penebar Swadaya.

Riduwan. (2008). Skala Pengukuran Variabelvariabel Penelitian. Bandung: Alfabeta.

Silalahi, F. R., Masrizal, \& Marbun, A. (2014). Motivasi Petani Dalam Usahatani Tanaman Gambir (Uncaria gambir roxb) Di Kecamatan Sutera Kabupaten Pesisir Selatan. Agrica Ekstensia, 5864.

Soekartawi. (1998). Prinsip Dasar Manajemen Pemasaran Hasil Pertanian Teori dan Aplikasi . Jakarta: Rajawali Pers.

Uno, H. B. (2016). Teori Motivasi dan Pengukurannya. Jakarta: Bumi Aksara. 